\title{
Evaluation of the Nutrient Status of Some Hydrophytes in the Water Courses of Nile Delta, Egypt
}

\author{
Kamal H. Shaltout, ${ }^{1}$ Tarek M. Galal, ${ }^{2}$ and Thanaa M. El-Komi1 ${ }^{1}$ \\ ${ }^{1}$ Botany Department, Faculty of Science, Tanta University, Tanta 31527, Egypt \\ ${ }^{2}$ Botany Department, Faculty of Science, Helwan University, Cairo 11792, Egypt
}

Correspondence should be addressed to Kamal H. Shaltout, kshaltout@yahoo.com

Received 8 April 2009; Accepted 22 June 2009

Recommended by Philip White

The nutritive values of three dominant hydrophytes along the water courses in Nile Delta, Egypt (Echinochloa stagnina, Eichhornia crassipes, and Ceratophyllum demersum) were evaluated in terms of estimating their phytomass, organic, and inorganic chemical compositions. Shoots were collected seasonally from 25 permanent stands representing the distribution of the three species along 15 canals and 10 drains distributed in 5 localities within the Nile Delta. Living and dead parts and total phytomass were estimated. Their inorganic $(\mathrm{Na}, \mathrm{K}, \mathrm{Ca}, \mathrm{Mg}, \mathrm{P}, \mathrm{Cu}, \mathrm{Mn}$, and $\mathrm{Pb}$ ) and organic (carbohydrates, total nitrogen, total protein, ether extract, digestible nutrient, digestible energy, metabolized energy, and net energy) contents were estimated. The vegetative phase of $E$. stagnina extended during winter, spring, and summer, while it is flowering and fruiting during autumn . On the other hand, E. crassipes and $C$. demersum attained their maximum flowering during spring and maximum fruiting during summer, while maximum vegetative phase during autumn and winter. E. stagnina had the highest mean annual phytomass, while C. demersum had the lowest. The living parts of $C$. demersum had the highest concentrations of $\mathrm{Na}, \mathrm{Ca}$, and $\mathrm{Mg}$, while the living parts of $E$. crassipes had the highest of $\mathrm{K}$ and N. C. demersum had the ability to accumulate more concentrations of heavy metals than the other studied species. E. crassipes had the highest values of total carbohydrate and total proteins, while E. stagnina had the highest of crude fibers, and C. demersum had the highest of ether extract and ash contents. The living parts of E. crassipes and C. demersum were considered as excellent forages, while the dead parts of all species and the living parts of E. stagnina were evaluated as poor forage.

Copyright (C) 2009 Kamal H. Shaltout et al. This is an open access article distributed under the Creative Commons Attribution License, which permits unrestricted use, distribution, and reproduction in any medium, provided the original work is properly cited.

\section{Introduction}

In Egypt, the serious problem of feed shortage, especially green summer fodder, suppresses the improvement of animal production. Therefore, dependence on improving local food and food resources for both animals and humans is necessary for a sound policy. The animal feeding system is depending on the cultivation of Egyptian clover (Trifolium alexandrinum L.). It produces around 4.8 million ton of starch per year and could cover the requirements of animals with surplus of 0.9 million ton of starch. However, in summer period, there will be at least a deficiency of 1.5 million ton of starch, and most animals are in fact in a starving condition receiving less than their maintenance requirements [1]. This calls for studying other nonconventional sources of feed.
Aquatic plants can cause problems with navigation, agriculture, fisheries, and public health. However, they play an important role in organic production of most inland water systems, and through photosynthesis, oxygen releases and enriches the aeration of the water system. In addition, some hydrophytes help in stabilizing the bottoms, prevent the erosion of the banks, and removing the toxic compounds through absorption of nutrients from the water and upper bottom sediments [2]. Aquatic plants also provide shelter and nourishment to fish, water fowl, and other aquatic organisms; some of them are hosts for many epiphytes and provide source for paper pulp, fiber, and bioenergy. For example, many species of Ceratophyllum, Lemna and Potamogeton are eaten by birds [3]. Some other roles of hydrophytes in the ecosystem are: soil stabilizers, nutrient cyclers, nutrient pump from the soil, water purifications, 
and as a source of food for terrestrial organisms such as birds and man [4]. Other uses of fresh water weeds are for biogas production, fuel, fertilizer, soil additives or mulch, mushroom culture, paints [5], and the reduction of water pollutants from paper-pulp mills, tanneries [6], and rubber and oil palm industries [7].

The utilization of aquatic plants as natural filters for the abatement of pollutants transported by water in rivers or lakes is considered to be an effective, low-cost, and cleanup option to ameliorate the quality of surface waters. Indeed, aquatic plants have been extensively utilized in the last decades to clean pollutant water almost all over the world [8]. Moreover, aquatic plants play an important role in sequestering large quantities of nutrients [9] and metals [10-12] from the environment by storing them in the roots and/or shoots. Aquatic plants have high remediation potential for macronutrients because of their general fast growth and high biomass production. It is therefore important to evaluate the seasonal and spatial variations in plant accumulation in wetland systems in order to assess the potential for nutrient and metal removal by plant uptake and harvesting. The present study aims at evaluating the phytomass and nutritive values of three dominant hydrophytes along the water courses in Nile Delta, Egypt (Echinochloa stagnina, Eichhornia crassipes, and Ceratophyllum demersum) in terms of estimating the seasonal variation in their organic and inorganic chemical compositions. Such study may assist in understanding the importance of these plants in animal nutrition in Egypt.

\section{Study Area}

Geologically, the area of Nile Delta had been subjected to the same geologic events that affected the northern Egypt during the pre-Miocene geologic history. The Delta is bounded on the eastern side by a major upward zone which occupies most of north central Sinai. This zone extends westwards into "Cairo-Suez Anticlinal Horst" [13] and is followed, northwards, by a major downward zone which occupies most of the Delta and its extension into northwest Sinai. Because of the thouthands of years of agricultural activities, all soils, with exception of the northern most part, are manmade and are regarded as anthropic variants of the Gleysols and Fluvisols. The low layer Delta is flat separated from the open sea by a narrow belt of Silic semistatic (and partly dynamic) Ergosols. This sand dune bar grows in the littoral of the shallow sea and gradually separates closed lagoons, which consequently turn into salty lakes and then with the gradual silting into Marshy Solonchaks [14].

Most of the Egyptian cultivated land is irrigated by the river Nile through a network of canals and is drained by a similar network of drains. Most of these canals and drains were dug in the last 200 years [15]. The total length of both networks (excluding private ditches and drains) exceeds $47000 \mathrm{~km}$ : > $31000 \mathrm{~km}$ of canals and $>16000 \mathrm{~km}$ of drains [16].

Soil characters of the water courses in the middle Delta region, as estimated by El-Sheikh [17], indicated that most soils were consisted of silt (Table 1). The drains were characterized by higher salinity compared with canals. On the other hand, canals were characterized by higher $\mathrm{N}, \mathrm{K}$, and $\mathrm{Ca}$; but lower OM, P, Na, and $\mathrm{Mg}$ than drains. Comparing the water samples of canals with those of drains, it was obvious that the canal water is less saline and is characterized by lower values of the dissolved elements.

According to the map of the world distribution of arid regions [18], the northern part of the Nile Delta lies in the arid zone, and the southern part lies in the hyperarid zone. The climatic conditions are warm summer $\left(20\right.$ to $\left.30^{\circ} \mathrm{C}\right)$ and mild winter $\left(10\right.$ to $20^{\circ} \mathrm{C}$ ). Though occasional short rainstorms occur in winter, most of the days are suny. The aridity index (P/PET) is between 0.03 and 0.20 at the North of the Delta (arid region) and less than 0.03 at the south (hyperarid region), where $\mathrm{P}$ is the annual precipitation, and PET is the potential evapotranspiration.

\section{Materials and Methods}

Twenty-five permanent sites (quadrats of $1 \mathrm{~m}^{2}$ ) were selected to represent the distribution of three aquatic species along 15 canals and 10 drains distributed in 5 localities within the Nile Delta region (Figure 1). These species are Echinochloa stagnina (C.Mast.) Solms, (emergent), Eichhornia crassipes (C.Mast.) Solms, (free floating), and Ceratophyllum demersum L. (submergent). In each quadrat, the shoots of plants were harvested, separated into living and dead parts, and weighted. The oven dry weights at $105^{\circ} \mathrm{C}$ were estimated for the living parts, dead parts and total phytomass (gm dry weight $\mathrm{m}^{-2}$ ). Composite samples were collected from living and dead parts of the shoots of each species, cleaned, dried at $60^{\circ} \mathrm{C}$, and powdered in a metal-free plastic mill. $\mathrm{Na}, \mathrm{K}$, and $\mathrm{Ca}$ were analyzed using flame photometer, $\mathrm{Fe}, \mathrm{Mg}, \mathrm{Cu}$, $\mathrm{Mn}, \mathrm{Zn}$, and $\mathrm{Pb}$ using Atomic Absorption and $\mathrm{P}$, and $\mathrm{N}$ by spectrophotometer. Ash content was estimated by ignition at $500^{\circ} \mathrm{C}$ for about 24 hours. Ether extract (total lipids) was determined by extracting the plant with ether, and crude fiber was determined by the soxhlet extraction method. All these procedures are outlined by Allen et al. [19]. Crude protein (CP) was calculated by multiplying the insoluble nitrogen by the factor of 6.25 [20].

Digestible crude protein (DCP) was calculated according to the equation of Demarquilly and Weiss [21]:

$$
\mathrm{DCP}(\text { in } \% \mathrm{DM})=0.929 \mathrm{CP}(\text { in } \% \mathrm{DM})-3.52 \text {. }
$$

Carbohydrates (NFE) were calculated from the following equation [22]:

$$
\mathrm{NFE}(\text { in } \% \mathrm{DM})=100-(\mathrm{CP}+\mathrm{CF}+\mathrm{FAT}+\mathrm{MINS}) \text {, }
$$

where CF is the crude fibre, and MINS is the total minerals.

Total digestible nutrients (TDNs) were estimated according to the equation applied by Naga and El- Shazly [23]:

$$
\operatorname{TDN}(\text { in } \% \mathrm{DM})=0.62(100+1.25 \mathrm{EE})-\mathrm{PK},
$$

where EE is the percentage of ether extract, $\mathrm{P}$ is the percentage of crude protein, and $\mathrm{K}$ is the coefficient that depends on the protein and fiber contents (0.7). 
TABLE 1: Mean and coefficient of variation (CV) of some characters of soil (a) and water (b) samples collected from canals and drains in the Nile Delta (after El-Sheikh 1989).

(a) Soil

\begin{tabular}{|c|c|c|c|c|c|c|c|c|c|c|c|c|c|}
\hline $\begin{array}{l}\text { Water } \\
\text { course }\end{array}$ & Sand $\%$ & Silt $\%$ & Clay $\%$ & OM\% & $\mathrm{CaCo}_{3} \%$ & $\begin{array}{l}\mathrm{EC} \mu \mathrm{mohs} \\
\mathrm{cm}^{-1}\end{array}$ & $\mathrm{pH}$ & $\begin{array}{l}\mathrm{N} \mathrm{mg} 100 \\
\mathrm{gm}^{-1}\end{array}$ & $\begin{array}{l}\text { P mg } 100 \\
\mathrm{gm}^{-1}\end{array}$ & $\begin{array}{l}\mathrm{K} \text { mg } 100 \\
\mathrm{gm}^{-1}\end{array}$ & $\begin{array}{l}\text { Na mg } 100 \\
\mathrm{gm}^{-1}\end{array}$ & $\begin{array}{l}\text { Ca mg } 100 \\
\mathrm{gm}^{-1}\end{array}$ & $\begin{array}{l}\mathrm{Mg} \text { mg } 100 \\
\mathrm{gm}^{-1}\end{array}$ \\
\hline \multicolumn{14}{|c|}{ Terrace Zone } \\
\hline \multicolumn{14}{|l|}{ Canal } \\
\hline Mean & 44.9 & 42.9 & 11.9 & 6.3 & 3.4 & 1523 & 7.7 & 249 & 8.2 & 111 & 274 & 1980 & 263 \\
\hline $\mathrm{CV}$ & 0.2 & 0.1 & 0.6 & 0.1 & 0.5 & 0.4 & 0.0 & 0.1 & 0.2 & 0.2 & 0.1 & 0.2 & 0.1 \\
\hline \multicolumn{14}{|l|}{ Drain } \\
\hline Mean & 41.5 & 47.5 & 11.3 & 6.8 & 2.9 & 2479 & 7.8 & 204 & 11.8 & 84 & 340 & 1546 & 301 \\
\hline $\mathrm{CV}$ & 0.1 & 0.1 & 0.9 & 0.1 & 0.4 & 0.1 & 0.0 & 0.2 & 0.2 & 0.2 & 0.1 & 0.1 & 0.1 \\
\hline \multicolumn{14}{|c|}{ Slope Zone } \\
\hline \multicolumn{14}{|l|}{ Canal } \\
\hline Mean & 42.8 & 45.2 & 11.8 & 6.8 & 2.1 & 418 & 7.8 & 256 & 7.7 & 80 & 137 & 1572 & 257 \\
\hline $\mathrm{CV}$ & 0.1 & 0.0 & 0.4 & 0.2 & 0.2 & 0.3 & 0.0 & 0.2 & 0.1 & 0.3 & 0.1 & 0.2 & 0.1 \\
\hline \multicolumn{14}{|l|}{ Drain } \\
\hline Mean & 40.8 & 43.2 & 15.9 & 7.7 & 2.3 & 2154 & 7.8 & 209 & 11.4 & 74 & 348 & 1518 & 322 \\
\hline $\mathrm{CV}$ & 0.2 & 0.1 & 0.6 & 0.2 & 0.2 & 0.7 & 0.0 & 0.2 & 0.3 & 0.3 & 0.4 & 0.1 & 0.1 \\
\hline
\end{tabular}

(b) Water

\begin{tabular}{|c|c|c|c|c|c|c|c|c|c|c|c|c|}
\hline $\begin{array}{l}\text { Water } \\
\text { course }\end{array}$ & $\begin{array}{l}\mathrm{EC} \mu \mathrm{mohs} \\
\mathrm{cm}^{-1}\end{array}$ & $\mathrm{pH}$ & $\begin{array}{l}\mathrm{N} \\
\mathrm{mg} \\
\mathrm{L}^{-1}\end{array}$ & $\begin{array}{l}\mathrm{P} \\
\mathrm{mg} \\
\mathrm{L}^{-1}\end{array}$ & $\begin{array}{l}\mathrm{K} \\
\mathrm{mg} \\
\mathrm{L}^{-1}\end{array}$ & $\begin{array}{l}\mathrm{Na} \\
\mathrm{mg} \\
\mathrm{L}^{-1}\end{array}$ & $\begin{array}{l}\mathrm{Ca} \\
\mathrm{mg} \\
\mathrm{L}^{-1}\end{array}$ & $\begin{array}{l}\mathrm{Mg} \\
\mathrm{mg} \\
\mathrm{L}^{-1}\end{array}$ & $\begin{array}{l}\mathrm{Co}_{3} \\
\mathrm{mg} \\
\mathrm{L}^{-1}\end{array}$ & $\begin{array}{l}\mathrm{HCO}_{3} \\
\mathrm{mg} \\
\mathrm{L}^{-1}\end{array}$ & $\begin{array}{l}\mathrm{Cl} \\
\mathrm{mg} \\
\mathrm{L}^{-1}\end{array}$ & $\begin{array}{l}\mathrm{So}_{4} \\
\mathrm{mg} \\
\mathrm{L}^{-1}\end{array}$ \\
\hline \multicolumn{13}{|l|}{ Canals } \\
\hline Mean & 350.0 & 7.7 & 1.6 & 0.5 & 17.3 & 80.0 & 39.5 & 9.2 & 21.0 & 183.0 & 62.0 & 334.3 \\
\hline $\mathrm{CV}$ & 0.1 & 0.2 & 0.7 & 0.2 & 0.1 & 0.1 & 0.1 & 0.1 & 0.3 & 0.2 & 0.2 & 0.2 \\
\hline \multicolumn{13}{|l|}{ Drains } \\
\hline Mean & 1385.0 & 7.6 & 1.4 & 1.0 & 19.3 & 157.9 & 57.0 & 12.3 & 31.1 & 300.1 & 232.0 & 364.5 \\
\hline $\mathrm{CV}$ & 0.2 & 0.0 & 1.0 & 0.6 & 0.6 & 0.01 & 0.04 & 0.3 & 0.0 & 0.0 & 0.2 & 0.2 \\
\hline
\end{tabular}

Digestible energy (DE) was estimated following this equation [24]:

$$
\begin{aligned}
\mathrm{DE}(\text { Mcal kg-1) }= & 0.0504 \mathrm{CP}(\%)+0.077 \mathrm{EE}(\%) \\
& +0.02 \mathrm{CF}(\%)+0.000377 \mathrm{NFE}^{2}(\%) \\
& +0.011 \mathrm{NFE}(\%)-0.152 .
\end{aligned}
$$

Metabolized energy (ME) is 0.82 DE [25], and net energy (NE) is $1 / 2 \mathrm{ME}$. [24]:

Gross energy (GE) was calculated following this equation

$\mathrm{GE}\left(\right.$ Kcal $\left.100 \mathrm{~g}^{-1}\right)=5.72 \mathrm{CP}+9.5 \mathrm{EE}+4.79 \mathrm{CF}+4.03 \mathrm{NFE}$.

One-way ANOVA was applied to assess the significance of variations in standing crop phytomass, elements, organic components, and nutritive variables in relation to the type of water course and the season [26].

\section{Results}

Phenological behavior of the studied species indicated that the vegetative phase E. stagnina extended during winter, spring, and summer, it is while flowering and fruiting during autumn (Figure 2). On the other hand, E. crassipes and $C$. demersum attained their maximum flowering during spring and maximum fruiting during summer, while maximum vegetative phase during autumn and winter. There was no pronounced sprouting of $C$. demersum.

The seasonal variation in the living and dead parts indicated that the living parts of E. stagnina and $C$. demersum attained their highest phytomass (866.8 and $200.1 \mathrm{gm}^{-2}$, resp.) during autumn, while those of E. crassipes $\left(647.6 \mathrm{gm}^{-2}\right)$ in summer (Figure 3$)$. On the other hand, the dead parts of E. stagnina had their highest value $\left(223.8 \mathrm{gm}^{-2}\right)$ in autumn and E. crassipes $\left(208.8 \mathrm{gm}^{-2}\right)$ in winter. E. stagnina had the highest mean annual phytomass $\left(801.1 \mathrm{gm}^{-2}\right)$, while $C$. demersum had the lowest $\left(160.9 \mathrm{~g} \mathrm{~m}^{-2}\right)$.

Living parts of $C$. demersum had the highest concentrations of $\mathrm{Na}\left(37.5 \mathrm{mg} \mathrm{g}^{-1}\right), \mathrm{Ca}\left(35.8 \mathrm{mg} \mathrm{g}^{-1}\right), \mathrm{Mg}(25.0 \mathrm{mg}$ $\left.\mathrm{g}^{-1}\right), \mathrm{P}\left(0.8 \mathrm{mg} \mathrm{g}^{-1}\right)$, and $\mathrm{Mn}\left(1467.0 \mu \mathrm{g} \mathrm{g}^{-1}\right)$ in autumn, but 
TABLE 2: Variation in the mean concentration \pm standard deviation of the different macronutrients in the living (L) and dead (D) parts of the studied species in relation to different seasons.

\begin{tabular}{|c|c|c|c|c|c|c|c|}
\hline Variable & & $\mathrm{Na} \mathrm{mg} \mathrm{g}^{-1}$ & $\mathrm{Kmg} \mathrm{g}^{-1}$ & $\mathrm{Ca} \mathrm{mg} \mathrm{g}^{-1}$ & $\mathrm{Mg} \mathrm{mg} \mathrm{g}^{-1}$ & $\mathrm{Nmg} \mathrm{g}^{-1}$ & $\mathrm{P} \mathrm{mg} \mathrm{g}^{-1}$ \\
\hline & \multicolumn{7}{|c|}{ Echinochloa stagnina } \\
\hline \multirow[t]{2}{*}{ Winter } & $\mathrm{L}$ & $25.2 \pm 1.3$ & $23.4 \pm 0.7$ & $15.1 \pm 0.4$ & $8.7 \pm 0.4$ & $10.9 \pm 0.2$ & $0.3 \pm 0.1$ \\
\hline & $\mathrm{D}$ & $16.5 \pm 0.7$ & $12.5 \pm 0.1$ & $11.4 \pm 0.1$ & $8.7 \pm 0.1$ & $7.5 \pm 0.2$ & $0.2 \pm 0.1$ \\
\hline \multirow[t]{2}{*}{ Spring } & $\mathrm{L}$ & $16.1 \pm 0.8$ & $21.7 \pm 0.6$ & $12.7 \pm 0.4$ & $8.8 \pm 0.5$ & $7.0 \pm 0.3$ & $0.3 \pm 0.1$ \\
\hline & $\mathrm{D}$ & $14.0 \pm 0.4$ & $11.5 \pm 0.2$ & $9.2 \pm 0.1$ & 7. $9 \pm 0.4$ & $4.2 \pm 0.2$ & $0.2 \pm 0.1$ \\
\hline \multirow[t]{2}{*}{ Summer } & $\mathrm{L}$ & $21.7 \pm 1.1$ & $24.3 \pm 0.9$ & $14.2 \pm 0.5$ & $5.4 \pm 0.3$ & $8.5 \pm 0.3$ & $0.3 \pm 0.1$ \\
\hline & $\mathrm{D}$ & $20.4 \pm 0.8$ & $12.9 \pm 0.3$ & $10.6 \pm 0.2$ & $7.8 \pm 0.2$ & $7.1 \pm 0.3$ & $0.1 \pm 0.1$ \\
\hline \multirow[t]{2}{*}{ Autumn } & $\mathrm{L}$ & $26.0 \pm 1.0$ & $21.6 \pm 0.7$ & $14.0 \pm 0.4$ & $8.3 \pm 0.4$ & $8.3 \pm 0.2$ & $0.3 \pm 0.1$ \\
\hline & $\mathrm{D}$ & $14.3 \pm 0.3$ & $10.0 \pm 0.1$ & $8.0 \pm 0.1$ & $9.5 \pm 0.3$ & $5.6 \pm 0.3$ & $0.2 \pm 0.1$ \\
\hline \multirow[t]{2}{*}{ Annual mean } & $\mathrm{L}$ & $22.3 \pm 4.5$ & $22.8 \pm 1.3$ & $14.0 \pm 0.9$ & $7.8 \pm 1.6$ & $8.7 \pm 1.6$ & $0.3 \pm 0.0$ \\
\hline & $\mathrm{D}$ & $16.3 \pm 2.9$ & $11.7 \pm 1.3$ & $9.8 \pm 1.5$ & $8.7 \pm 0.9$ & $6.1 \pm 1.5$ & $0.2 \pm 0.1$ \\
\hline \multirow[t]{3}{*}{ F-value } & $\mathrm{L}$ & $4.35^{* *}$ & ns & ns & $4.50^{* *}$ & ns & ns \\
\hline & $\mathrm{D}$ & ns & ns & ns & $4.48^{*}$ & ns & Ns \\
\hline & \multicolumn{7}{|c|}{ Eichhornea crassipes } \\
\hline \multirow[t]{2}{*}{ Winter } & $\mathrm{L}$ & $17.4 \pm 0.8$ & $27.4 \pm 1.2$ & $26.5 \pm 0.7$ & $11.3 \pm 0.3$ & $6.7 \pm 0.1$ & $0.3 \pm 0.1$ \\
\hline & $\mathrm{D}$ & $32.8 \pm 1.9$ & $14.3 \pm 0.5$ & $20.6 \pm 0.1$ & $10.1 \pm 0.1$ & $1.6 \pm 0.1$ & $0.2 \pm 0.1$ \\
\hline \multirow[t]{2}{*}{ Spring } & $\mathrm{L}$ & $21.0 \pm 0.6$ & $31.2 \pm 1.1$ & $30.0 \pm 0.4$ & $16.3 \pm 0.2$ & $12.9 \pm 0.2$ & $0.5 \pm 0.1$ \\
\hline & $\mathrm{D}$ & $28.7 \pm 1.2$ & $17.4 \pm 0.4$ & $21.7 \pm 0.1$ & $15.3 \pm 0.1$ & $3.0 \pm 0.1$ & $0.2 \pm 0.1$ \\
\hline \multirow[t]{2}{*}{ Summer } & $\mathrm{L}$ & $22.5 \pm 1.0$ & $30.4 \pm 1.3$ & $27.8 \pm 0.4$ & $13.3 \pm 0.4$ & $19.7 \pm 0.3$ & $0.4 \pm 0.1$ \\
\hline & $\mathrm{D}$ & $36.8 \pm 2.9$ & $18.0 \pm 1.2$ & $25.8 \pm 0.3$ & $14.7 \pm 0.2$ & $3.3 \pm 0.1$ & $0.2 \pm 0.1$ \\
\hline \multirow[t]{2}{*}{ Autumn } & $\mathrm{L}$ & $21.4 \pm 1.0$ & $38.3 \pm 1.1$ & $28.7 \pm 0.4$ & $18.3 \pm 0.6$ & $26.5 \pm 0.8$ & $0.7 \pm 0.1$ \\
\hline & $\mathrm{D}$ & $27.1 \pm 1.1$ & $23.6 \pm 0.3$ & $19.2 \pm 0.3$ & $21.1 \pm 1.9$ & $4.0 \pm 0.1$ & $0.2 \pm 0.1$ \\
\hline \multirow[t]{2}{*}{ Annual mean } & $\mathrm{L}$ & $20.6 \pm 2.2$ & $31.8 \pm 4.6$ & $28.3 \pm 1.5$ & $14.8 \pm 3.1$ & $16.5 \pm 8.5$ & $0.5 \pm 0.2$ \\
\hline & $\mathrm{D}$ & $31.4 \pm 4.4$ & $18.3 \pm 3.9$ & $21.8 \pm 2.8$ & $15.3 \pm 4.5$ & $3.0 \pm 1.0$ & $0.2 \pm 0.0$ \\
\hline \multirow[t]{3}{*}{ F-value } & $\mathrm{L}$ & $4.39 * *$ & $3.13^{*}$ & $3.61^{*}$ & $12.82 * * *$ & $20.39 * * *$ & $5.50^{* *}$ \\
\hline & $\mathrm{D}$ & - & - & - & - & - & - \\
\hline & \multicolumn{7}{|c|}{ Ceratophyllum demersum } \\
\hline Winter & & $28.0 \pm 0.5$ & $29.3 \pm 0.6$ & $31.5 \pm 0.7$ & $14.5 \pm 0.5$ & $20.8 \pm 0.1$ & $0.7 \pm 0.2$ \\
\hline Spring & & $29.6 \pm 0.6$ & $31.5 \pm 0.6$ & $32.7 \pm 0.6$ & $17.5 \pm 0.6$ & $20.4 \pm 0.2$ & $0.6 \pm 0.2$ \\
\hline Summer & & $29.7 \pm 0.8$ & $29.2 \pm 0.7$ & $33.0 \pm 0.9$ & $24.5 \pm 1.1$ & $25.4 \pm 0.5$ & $0.6 \pm 0.2$ \\
\hline Autumn & & $37.5 \pm 1.1$ & $36.0 \pm 0.7$ & $35.8 \pm 1.5$ & $25.0 \pm 0.9$ & $24.0 \pm 0.5$ & $0.8 \pm 0.2$ \\
\hline Annual mean & & $31.2 \pm 4.3$ & $31.5 \pm 3.2$ & $33.3 \pm 1.8$ & $20.4 \pm 5.2$ & $22.7 \pm 2.4$ & $0.7 \pm 0.1$ \\
\hline F-value & & $\mathrm{ns}$ & $\mathrm{ns}$ & ns & ns & ns & $11.43^{* * *}$ \\
\hline
\end{tabular}

${ }^{*} P<.05,{ }^{* *} P<.01,{ }^{* * *} P<.001$, ns: insignificant difference $(P>.05)$.

$\mathrm{Cu}$ and $\mathrm{Pb}$ (54.7 and $127.6 \mu \mathrm{g} \mathrm{g}^{-1}$, resp.) in summer (Tables 2 and 3). On the other hand, the living parts of E. crassipes had the highest values of $\mathrm{K}$ and $\mathrm{N}$ (38.3 and $26.5 \mathrm{mg} \mathrm{g}^{-1}$, resp.) in autumn. The living parts of E. stagnina had the lowest values of $\mathrm{Mg}$ and $\mathrm{Cu}$ in summer and $\mathrm{Mn}$ in autumn, while the dead parts had the lowest of $\mathrm{Na}$ in spring, $\mathrm{P}$ in summer, and $\mathrm{K}$ and Ca in autumn.

According to the organic contents in the living and dead shoot parts, the living parts of E. crassipes had the highest value of total carbohydrates, NFE (61.9\%), but the lowest of ether extract $(\mathrm{EE}=0.8 \%)$ in winter and the highest total protein, TP (16.6\%), but the lowest crude fiber, CF (11.9\%), in autumn (Table 4). On the other hand, the living parts of $C$. demersum attained their highest values of EE and ash (2.1\% and $30.9 \%$, resp.), but the lowest of NFE $(31.6 \%)$ in autumn. Moreover, the dead parts of E. stagnina had the highest CF (29.4\%), while the living parts had the lowest ash $(11.6 \%)$ in autumn. E. crassipes had the highest values of total 
TABLE 3: Variation in the mean concentration \pm standard deviation of the different micronutrients in the living (L) and dead (D) parts of the studied species in relation to different seasons.

\begin{tabular}{|c|c|c|c|c|}
\hline \multicolumn{2}{|c|}{ Variable } & $\mathrm{Cu} \mu \mathrm{g} \mathrm{g}^{-1}$ & $\mathrm{Mn}_{\mu \mathrm{g} \mathrm{g}^{-1}}$ & $\mathrm{~Pb} \mu \mathrm{g} \mathrm{g}^{-1}$ \\
\hline & \multicolumn{4}{|c|}{ Echinochloa stagnina } \\
\hline \multirow[t]{2}{*}{ Winter } & $\mathrm{L}$ & $18.6 \pm 0.6$ & $153.4 \pm 78.0$ & $51.1 \pm 26.2$ \\
\hline & $\mathrm{D}$ & $21.2 \pm 2.3$ & $231.0 \pm 11.3$ & $52.6 \pm 14.8$ \\
\hline \multirow[t]{2}{*}{ Spring } & $\mathrm{L}$ & $26.5 \pm 0.8$ & $148.0 \pm 64.5$ & $51.4 \pm 36.8$ \\
\hline & $\mathrm{D}$ & $34.5 \pm 6.9$ & $209.6 \pm 41.6$ & $64.3 \pm 18.6$ \\
\hline \multirow[t]{2}{*}{ Summer } & $\mathrm{L}$ & $12.9 \pm 6.1$ & $102.5 \pm 61.8$ & $59.7 \pm 40.7$ \\
\hline & $\mathrm{D}$ & $44.5 \pm 6.1$ & $180.2 \pm 44.5$ & $43.3 \pm 17.1$ \\
\hline \multirow[t]{2}{*}{ Autumn } & $\mathrm{L}$ & $16.4 \pm 8.8$ & $90.3 \pm 12.4$ & $74.6 \pm 63.3$ \\
\hline & $\mathrm{D}$ & $20.5 \pm 9.6$ & $240.1 \pm 98.0$ & $72.8 \pm 28.2$ \\
\hline \multirow[t]{2}{*}{ Annual mean } & $\mathrm{L}$ & $18.6 \pm 5.8$ & $123.6 \pm 31.8$ & $59.2 \pm 11.0$ \\
\hline & $\mathrm{D}$ & $30.2 \pm 11.5$ & $215.2 \pm 26.6$ & $58.3 \pm 12.9$ \\
\hline \multirow[t]{3}{*}{ F-value } & $\mathrm{L}$ & $3.69^{* *}$ & $7.29 * * *$ & ns \\
\hline & $\mathrm{D}$ & ns & ns & ns \\
\hline & \multicolumn{4}{|c|}{ Eichhornea crassipes } \\
\hline \multirow[t]{2}{*}{ Winter } & $\mathrm{L}$ & $24.8 \pm 9.3$ & $294.8 \pm 114.0$ & $57.7 \pm 33.9$ \\
\hline & $\mathrm{D}$ & $17.8 \pm 4.1$ & $201.2 \pm 44.0$ & $38.9 \pm 16.1$ \\
\hline \multirow[t]{2}{*}{ Spring } & $\mathrm{L}$ & $46.2 \pm 12.6$ & $294.2 \pm 156.0$ & $86.3 \pm 48.7$ \\
\hline & $\mathrm{D}$ & $33.2 \pm 8.1$ & $231.5 \pm 68.0$ & $59.2 \pm 26.1$ \\
\hline \multirow[t]{2}{*}{ Summer } & $\mathrm{L}$ & $34.5 \pm 11.6$ & $331.7 \pm 108.0$ & $50.7 \pm 31.0$ \\
\hline & $\mathrm{D}$ & $13.7 \pm 5.9$ & $385.0 \pm 296.0$ & $33.0 \pm 12.3$ \\
\hline \multirow[t]{2}{*}{ Autumn } & $\mathrm{L}$ & $31.3 \pm 12.5$ & $225.0 \pm 84.0$ & $62.2 \pm 53.0$ \\
\hline & $\mathrm{D}$ & $41.9 \pm 18.7$ & $746.5 \pm 112.0$ & $55.5 \pm 32.7$ \\
\hline \multirow[t]{2}{*}{ Annual mean } & $\mathrm{L}$ & $34.2 \pm 8.9$ & $286.4 \pm 44.5$ & $64.2 \pm 15.5$ \\
\hline & $\mathrm{D}$ & $26.7 \pm 13.2$ & $391.1 \pm 250.3$ & $46.7 \pm 12.7$ \\
\hline \multirow[t]{3}{*}{ F-value } & $\mathrm{L}$ & $6.15^{* *}$ & ns & ns \\
\hline & $\mathrm{D}$ & - & - & - \\
\hline & \multicolumn{4}{|c|}{ Ceratophyllum demersum } \\
\hline \multicolumn{2}{|l|}{ Winter } & $33.4 \pm 7.5$ & $817.7 \pm 375.9$ & $99.2 \pm 27.8$ \\
\hline \multicolumn{2}{|l|}{ Spring } & $39.5 \pm 9.0$ & $1131.2 \pm 593.7$ & $103.5 \pm 36.2$ \\
\hline \multicolumn{2}{|l|}{ Summer } & $54.7 \pm 19.9$ & $1283.6 \pm 576.7$ & $127.6 \pm 34.5$ \\
\hline \multicolumn{2}{|l|}{ Autumn } & $44.2 \pm 21.5$ & $1467.0 \pm 920.0$ & $96.6 \pm 39.9$ \\
\hline \multicolumn{2}{|l|}{ Annual mean } & $42.0 \pm 8.0$ & $1174.9 \pm 274.9$ & $106.7 \pm 14.2$ \\
\hline \multicolumn{2}{|l|}{ F-value } & $6.19^{* *}$ & ns & $2.81^{*}$ \\
\hline
\end{tabular}

carbohydrate and total proteins, while E. stagnina had the highest of crude fibers, and $C$. demersum had the highest of ether extract and ash contents. Furthermore, the living parts of $C$. demersum had the highest annual mean values of total protein, ether extract, crude fiber, and ash content, while that of E. stagnina had the highest of total carbohydrates.

The variations in the nutritive value in the living and dead shoot parts for most of the studied species were significant in relation to the season. The highest value of digestible crude protein, DCP (11.3\%), was recorded in the living parts of E. crassipes in autumn and C. Demersum in summer, while the highest of total digestible nutrients, TDN $(68.1 \%)$, was recorded in the living parts of E. stagnina in winter (Table 5). The living parts of E. stagnina had the highest values of digestible energy, DE, metabolized energy, ME, and net energy, $\mathrm{NE}\left(2.8,2.3\right.$, and $1.2 \mathrm{Mcal} \mathrm{kg}^{-1}$, resp.), while the dead parts had the highest gross energy, GE $\left(391.3 \mathrm{Kcal} \mathrm{kg}^{-1}\right)$, in autumn. The living parts of $C$. 
TABLE 4: Variation in the mean organic contents in the above-ground living (L) and dead (D) parts of the studied species in relation to different seasons. NFE: total carbohydrates, TP: total protein, EE: ether extract, CF: crude fiber.

\begin{tabular}{|c|c|c|c|c|c|c|}
\hline Variable & & NFE & $\mathrm{TP}$ & $\mathrm{EE}$ & $\mathrm{CF}$ & Ash \\
\hline & \multicolumn{6}{|c|}{ Echinochloa stagnina } \\
\hline \multirow[t]{2}{*}{ Winter } & $\mathrm{L}$ & $53.1 \pm 2.7$ & $6.8 \pm 1.3$ & $1.6 \pm 0.3$ & $24.9 \pm 1.7$ & $13.6 \pm 0.7$ \\
\hline & $\mathrm{D}$ & $56.1 \pm 0.4$ & $4.7 \pm 0.1$ & $1.6 \pm 0.2$ & $25.7 \pm 0.8$ & $11.9 \pm 1.1$ \\
\hline \multirow[t]{2}{*}{ Spring } & $\mathrm{L}$ & $54.0 \pm 3.8$ & $4.4 \pm 1.6$ & $1.0 \pm 0.4$ & $27.0 \pm 4.0$ & $13.6 \pm 1.5$ \\
\hline & $\mathrm{D}$ & $54.0 \pm 3.2$ & $2.6 \pm 1.5$ & $1.4 \pm 0.3$ & $25.5 \pm 2.6$ & $16.5 \pm 1.2$ \\
\hline \multirow[t]{2}{*}{ Summer } & $\mathrm{L}$ & $53.4 \pm 1.7$ & $5.3 \pm 2.0$ & $1.2 \pm 0.6$ & $27.5 \pm 2.2$ & $12.6 \pm 0.7$ \\
\hline & $\mathrm{D}$ & $52.2 \pm 4.5$ & $4.4 \pm 1.7$ & $1.5 \pm 0.4$ & $27.6 \pm 3.6$ & $14.3 \pm 1.2$ \\
\hline \multirow[t]{2}{*}{ Autumn } & $\mathrm{L}$ & $57.0 \pm 1.4$ & $5.2 \pm 1.4$ & $1.2 \pm 0.2$ & $25.0 \pm 1.7$ & $11.6 \pm 0.4$ \\
\hline & $\mathrm{D}$ & $52.5 \pm 6.0$ & $3.5 \pm 1.7$ & $1.8 \pm 0.6$ & $29.4 \pm 5.5$ & $12.8 \pm 3.7$ \\
\hline \multirow[t]{2}{*}{ Annual mean } & $\mathrm{L}$ & $54.4 \pm 1.8$ & $5.4 \pm 1.0$ & $1.3 \pm 0.3$ & $26.1 \pm 1.3$ & $12.9 \pm 0.9$ \\
\hline & $\mathrm{D}$ & $53.7 \pm 1.8$ & $3.8 \pm 0.9$ & $1.6 \pm 0.2$ & $27.1 \pm 1.8$ & $13.9 \pm 2.0$ \\
\hline \multirow[t]{3}{*}{ F-value } & $\mathrm{L}$ & ns & ns & ns & ns & $4.48^{*}$ \\
\hline & $\mathrm{D}$ & ns & ns & ns & $4.45^{*}$ & ns \\
\hline & \multicolumn{6}{|c|}{ Eichhornea crassipes } \\
\hline \multirow[t]{2}{*}{ Winter } & $\mathrm{L}$ & $61.9 \pm 3.4$ & $4.2 \pm 0.5$ & $0.8 \pm 0.2$ & $14.0 \pm 1.2$ & $19.1 \pm 1.9$ \\
\hline & $\mathrm{D}$ & $58.5 \pm 4.1$ & $1.0 \pm 0.4$ & $1.2 \pm 0.2$ & $20.7 \pm 1.3$ & $18.7 \pm 3.3$ \\
\hline \multirow[t]{2}{*}{ Spring } & $\mathrm{L}$ & $52.0 \pm 3.5$ & $8.1 \pm 0.9$ & $1.1 \pm 0.3$ & $17.1 \pm 1.6$ & $21.7 \pm 2.4$ \\
\hline & $\mathrm{D}$ & $49.2 \pm 2.8$ & $1.8 \pm 0.8$ & $1.6 \pm 0.1$ & $24.5 \pm 1.4$ & $22.8 \pm 1.6$ \\
\hline \multirow[t]{2}{*}{ Summer } & $\mathrm{L}$ & $50.0 \pm 6.5$ & $12.3 \pm 2.1$ & $1.2 \pm 0.5$ & $15.1 \pm 2.8$ & $21.4 \pm 4.4$ \\
\hline & $\mathrm{D}$ & $57.2 \pm 4.3$ & $2.1 \pm 0.9$ & $1.4 \pm 0.1$ & $19.8 \pm 3.5$ & $19.5 \pm 1.7$ \\
\hline \multirow[t]{2}{*}{ Autumn } & $\mathrm{L}$ & $50.4 \pm 5.8$ & $16.6 \pm 5.2$ & $1.8 \pm 0.3$ & $11.9 \pm 0.9$ & $19.3 \pm 1.3$ \\
\hline & $\mathrm{D}$ & $51.3 \pm 2.4$ & $2.5 \pm 0.6$ & $1.3 \pm 0.2$ & $22.9 \pm 2.8$ & $22.0 \pm 3.8$ \\
\hline \multirow[t]{2}{*}{ Annual mean } & $\mathrm{L}$ & $53.6 \pm 5.6$ & $10.3 \pm 5.3$ & $1.2 \pm 0.4$ & $14.5 \pm 2.2$ & $20.4 \pm 1.4$ \\
\hline & $\mathrm{D}$ & $54.1 \pm 4.5$ & $1.6 \pm 0.6$ & $1.4 \pm 0.2$ & $21.9 \pm 2.1$ & $20.8 \pm 1.9$ \\
\hline \multirow[t]{3}{*}{ F-value } & $\mathrm{L}$ & $8.27^{* * *}$ & $19.70^{* * *}$ & $17.58^{* * *}$ & $13.39^{* * *}$ & ns \\
\hline & $\mathrm{D}$ & - & - & - & - & - \\
\hline & \multicolumn{6}{|c|}{ Ceratophyllum demersum } \\
\hline \multicolumn{2}{|l|}{ Winter } & $31.8 \pm 2.3$ & $13.0 \pm 0.5$ & $1.6 \pm 0.4$ & $23.1 \pm 2.1$ & $30.5 \pm 1.9$ \\
\hline \multicolumn{2}{|l|}{ Spring } & $35.5 \pm 2.5$ & $12.8 \pm 1.3$ & $1.9 \pm 0.2$ & $21.7 \pm 1.5$ & $28.2 \pm 2.7$ \\
\hline \multicolumn{2}{|l|}{ Summer } & $34.6 \pm 7.3$ & $15.9 \pm 3.4$ & $1.5 \pm 0.5$ & $22.9 \pm 5.6$ & $24.8 \pm 1.7$ \\
\hline \multicolumn{2}{|l|}{ Autumn } & $31.6 \pm 11.6$ & $15.0 \pm 3.0$ & $2.1 \pm 0.5$ & $20.4 \pm 4.1$ & $30.9 \pm 7.4$ \\
\hline \multicolumn{2}{|l|}{ Annual mean } & $33.4 \pm 1.9$ & $14.2 \pm 1.5$ & $1.8 \pm 0.3$ & $22.0 \pm 1.2$ & $28.6 \pm 2.8$ \\
\hline \multicolumn{2}{|l|}{ F-value } & ns & ns & Ns & ns & $8.94^{* * *}$ \\
\hline
\end{tabular}

${ }^{*} P<.05,{ }^{* *} P<.01,{ }^{* * *} P<.001$, and ns: insignificant difference $(P>.05)$.

demersum had the lowest values of TDN, DE, ME, NE in winter, while the dead parts of E. crassipes attained the lowest GE in autumn. The living parts of E. stagnina had the highest annual mean values of total digestible nutrients, digestible energy, and metabolized energy, while those of $C$. demersum had the highest of digestible crude protein.

\section{Discussion}

Biomass estimation is an important tool in aquatic plant research for studies such as species distribution and abundance, succession, and assessment of weed management operations [27]. E. stagnina and C. demersum attained their maximum phytomass during autumn, while E. crassipes during summer. A similar finding was postulated by ElDarier and Sadek [28]. These results may be interpreted as E. stagnina flowered and fruited during autumn, while E. crassipes during summer. The highest mean annual phytomass of E. stagnina may be due to the rhizomatus nature of this plant which is believed to be more resistant than the other life forms to trampling along the canal terraces by farmers and their grazing animals. On the other hand, the lowest phytomass of $C$. demersum may be attributed partially to the shade caused by the tall crowdy plants (e.g. 
TABle 5: Nutritive value of the above-ground living (L) and dead (D) parts of the studied species in relation to different seasons. DCP: digestible crude protein, TDN: total digestible nutrients, DE: digestible energy, ME: metabolized energy, NE: net energy and GE; gross energy.

\begin{tabular}{|c|c|c|c|c|c|c|c|}
\hline \multirow[t]{2}{*}{ Variable } & & $\mathrm{DCP} \%$ & TDN\% & DE Mcal kg-1 & ME Mcal kg-1 & NE Mcal kg-1 & GE Kcal $100 g^{-1}$ \\
\hline & \multicolumn{7}{|c|}{ Echinochloa stagnina } \\
\hline \multirow[t]{2}{*}{ Winter } & $\mathrm{L}$ & $2.8 \pm 1.2$ & $68.1 \pm 1.1$ & $2.5 \pm 0.0$ & $2.1 \pm 0.0$ & $1.1 \pm 0.0$ & $384.8 \pm 7.5$ \\
\hline & $\mathrm{D}$ & $0.9 \pm 0.1$ & $66.7 \pm 0.1$ & $2.5 \pm 0.0$ & $2.1 \pm 0.0$ & $1.1 \pm 0.0$ & $393.0 \pm 3.9$ \\
\hline \multirow[t]{2}{*}{ Spring } & $\mathrm{L}$ & $0.9 \pm 1.1$ & $64.2 \pm 3.5$ & $2.6 \pm 0.3$ & $2.1 \pm 0.2$ & $1.1 \pm 0.1$ & $381.5 \pm 9.8$ \\
\hline & $\mathrm{D}$ & $0.1 \pm 0.2$ & $62.0 \pm 6.4$ & $2.3 \pm 0.1$ & $1.9 \pm 0.1$ & $1.0 \pm 0.0$ & $369.9 \pm 7.5$ \\
\hline \multirow[t]{2}{*}{ Summer } & $\mathrm{L}$ & $1.5 \pm 1.8$ & $66.7 \pm 1.5$ & $2.5 \pm 0.2$ & $2.1 \pm 0.1$ & $1.1 \pm 0.1$ & $388.6 \pm 3.9$ \\
\hline & $\mathrm{D}$ & $1.0 \pm 1.0$ & $63.1 \pm 3.8$ & $2.3 \pm 0.2$ & $1.9 \pm 0.2$ & $1.0 \pm 0.1$ & $385.9 \pm 13.0$ \\
\hline \multirow[t]{2}{*}{ Autumn } & $\mathrm{L}$ & $1.4 \pm 1.2$ & $66.7 \pm 1.2$ & $2.8 \pm 0.3$ & $2.3 \pm 0.3$ & $1.2 \pm 0.1$ & $386.3 \pm 6.4$ \\
\hline & $\mathrm{D}$ & $0.6 \pm 0.8$ & $61 . \pm 6.7$ & $2.4 \pm 0.1$ & $2.0 \pm 0.1$ & $1.0 \pm 0.1$ & $391.3 \pm 20.7$ \\
\hline \multirow[t]{2}{*}{ Annual mean } & $\mathrm{L}$ & $1.7 \pm 0.8$ & $66.4 \pm 1.6$ & $2.6 \pm 0.1$ & $2.2 \pm 0.1$ & $1.1 \pm 0.1$ & $385.3 \pm 2.9$ \\
\hline & $\mathrm{D}$ & $0.7 \pm 0.4$ & $63.4 \pm 2.3$ & $2.4 \pm 0.1$ & $2.0 \pm 0.1$ & $1.0 \pm 0.1$ & $385.0 \pm 10.5$ \\
\hline \multirow[t]{3}{*}{ F-value } & $\mathrm{L}$ & ns & $\mathrm{ns}$ & $\mathrm{ns}$ & ns & ns & $\mathrm{ns}$ \\
\hline & $\mathrm{D}$ & ns & ns & ns & ns & ns & ns \\
\hline & \multicolumn{7}{|c|}{ Eichhornea crassipes } \\
\hline \multirow[t]{2}{*}{ Winter } & $\mathrm{L}$ & $0.4 \pm 0.4$ & $51.4 \pm 1.4$ & $2.4 \pm 0.1$ & $2.0 \pm 0.1$ & $1.0 \pm 0.0$ & $345.5 \pm 8.0$ \\
\hline & $\mathrm{D}$ & $0.0 \pm 0.0$ & $51.5 \pm 2.0$ & $2.4 \pm 0.2$ & $2.0 \pm 0.2$ & $1.0 \pm 0.1$ & $357.0 \pm 12.7$ \\
\hline \multirow[t]{2}{*}{ Spring } & $\mathrm{L}$ & $3.7 \pm 0.9$ & $50.3 \pm 1.5$ & $2.5 \pm 0.4$ & $2.1 \pm 0.5$ & $1.1 \pm 0.2$ & $347.4 \pm 7.3$ \\
\hline & $\mathrm{D}$ & $0.0 \pm 0.0$ & $64.3 \pm 0.5$ & $2.1 \pm 0.1$ & $1.7 \pm 0.1$ & $0.9 \pm 0.0$ & $346.4 \pm 6.0$ \\
\hline \multirow[t]{2}{*}{ Summer } & $\mathrm{L}$ & $8.0 \pm 2.0$ & $57.5 \pm 5.8$ & $2.4 \pm 0.3$ & $2.0 \pm 0.2$ & $1.0 \pm 0.1$ & $356.8 \pm 18.0$ \\
\hline & $\mathrm{D}$ & $0.0 \pm 0.0$ & $55.9 \pm 7.5$ & $2.3 \pm 0.2$ & $1.9 \pm 0.1$ & $1.0 \pm 0.1$ & $355.5 \pm 5.4$ \\
\hline \multirow[t]{2}{*}{ Autumn } & $\mathrm{L}$ & $11.3 \pm 4.7$ & $57.7 \pm 8.0$ & $2.6 \pm 0.1$ & $2.1 \pm 0.1$ & $1.1 \pm 0.1$ & $387.0 \pm 29.0$ \\
\hline & $\mathrm{D}$ & $0.0 \pm 0.0$ & $60.7 \pm 8.2$ & $2.2 \pm 0.2$ & $1.8 \pm 0.1$ & $0.9 \pm 0.1$ & $324.7 \pm 42.0$ \\
\hline \multirow[t]{2}{*}{ Annual mean } & $\mathrm{L}$ & $5.9 \pm 4.8$ & $54.2 \pm 3.9$ & $2.5 \pm 0.1$ & $2.1 \pm 0.1$ & $1.1 \pm 0.1$ & $359.2 \pm 19.2$ \\
\hline & $\mathrm{D}$ & $0.0 \pm 0.0$ & $58.1 \pm 5.6$ & $2.3 \pm 0.1$ & $1.9 \pm 0.1$ & $1.0 \pm 0.1$ & $345.9 \pm 14.9$ \\
\hline \multirow[t]{3}{*}{ F-value } & $\mathrm{L}$ & $15.07 * * *$ & $4.86^{*}$ & $\mathrm{~ns}$ & ns & $\mathrm{ns}$ & $\mathrm{ns}$ \\
\hline & $\mathrm{D}$ & - & - & - & - & - & - \\
\hline & \multicolumn{7}{|c|}{ Ceratophyllum demersum } \\
\hline Winter & & $8.7 \pm 0.5$ & $45.4 \pm 4.8$ & $1.8 \pm 0.1$ & $1.5 \pm 0.1$ & $0.8 \pm 0.0$ & $330.2 \pm 10.4$ \\
\hline Spring & & $8.4 \pm 1.2$ & $49.4 \pm 4.8$ & $1.9 \pm 0.1$ & $1.6 \pm 0.1$ & $0.8 \pm 0.0$ & $339.9 \pm 16.6$ \\
\hline Summer & & $11.3 \pm 3.2$ & $49.6 \pm 5.6$ & $2.1 \pm 0.1$ & $1.7 \pm 0.1$ & $0.9 \pm 0.1$ & $357.0 \pm 10.2$ \\
\hline Autumn & & $10.5 \pm 2.8$ & $49.9 \pm 8.0$ & $2.0 \pm 0.2$ & $1.6 \pm 0.2$ & $0.8 \pm 0.1$ & $333.2 \pm 33.4$ \\
\hline Annual mean & & $9.7 \pm 1.4$ & $48.6 \pm 2.1$ & $2.0 \pm 0.1$ & $1.6 \pm 0.1$ & $0.8 \pm 0.1$ & $340.1 \pm 11.9$ \\
\hline F-value & & $\mathrm{ns}$ & $\mathrm{ns}$ & $5.42^{*}$ & $5.38^{*}$ & $5.47^{*}$ & $\mathrm{~ns}$ \\
\hline
\end{tabular}

${ }^{*} P<.05,{ }^{* *} P<.01,{ }^{* * *} P<.001$, and ns: insignificant difference $(P>.05)$.

Phragmites australis), which may influence the growth of some associated aquatic plants. This may also interpreted the view that plants under water will have lower availability of atmospheric oxygen and carbon dioxide [29]. The phytomass of $E$. crassipes in the present study is lower than that recorded by El-Fiky [30] along a drainage ditch in Giza and Reddy et al. [31] in some natural stands in Florida. On the other hand, the phytomass of E. stagnina and C. demersum is higher than that recorded by El-Fiky [30].

The successful living of aquatic macrophytes in polluted areas is usually due to its ability to accumulate larger metal concentrations than in the surrounding water [32]. Comparing the three studied species with Pistia stratiotes [33], it is clear that $\mathrm{Na}, \mathrm{Mg}, \mathrm{Fe}, \mathrm{Zn}$, and $\mathrm{Cu}$ are higher in the tissues of the three species than in $P$. stratiotes. In general, this comparison indicated that the studied plants had the ability to absorb heavy metals from the water courses and act as biofilter for these elements. It was obvious that $\mathrm{Mg}$ and Mn concentrations in $C$. demersum exceed the maximum values, while $\mathrm{Ca}$ and $\mathrm{P}$ approach the minimum, but $\mathrm{Na}$ exceeds the maximum in all plants [34]. Mjelde and Faafen [35] in their study on small Norwegian lakes observed that 


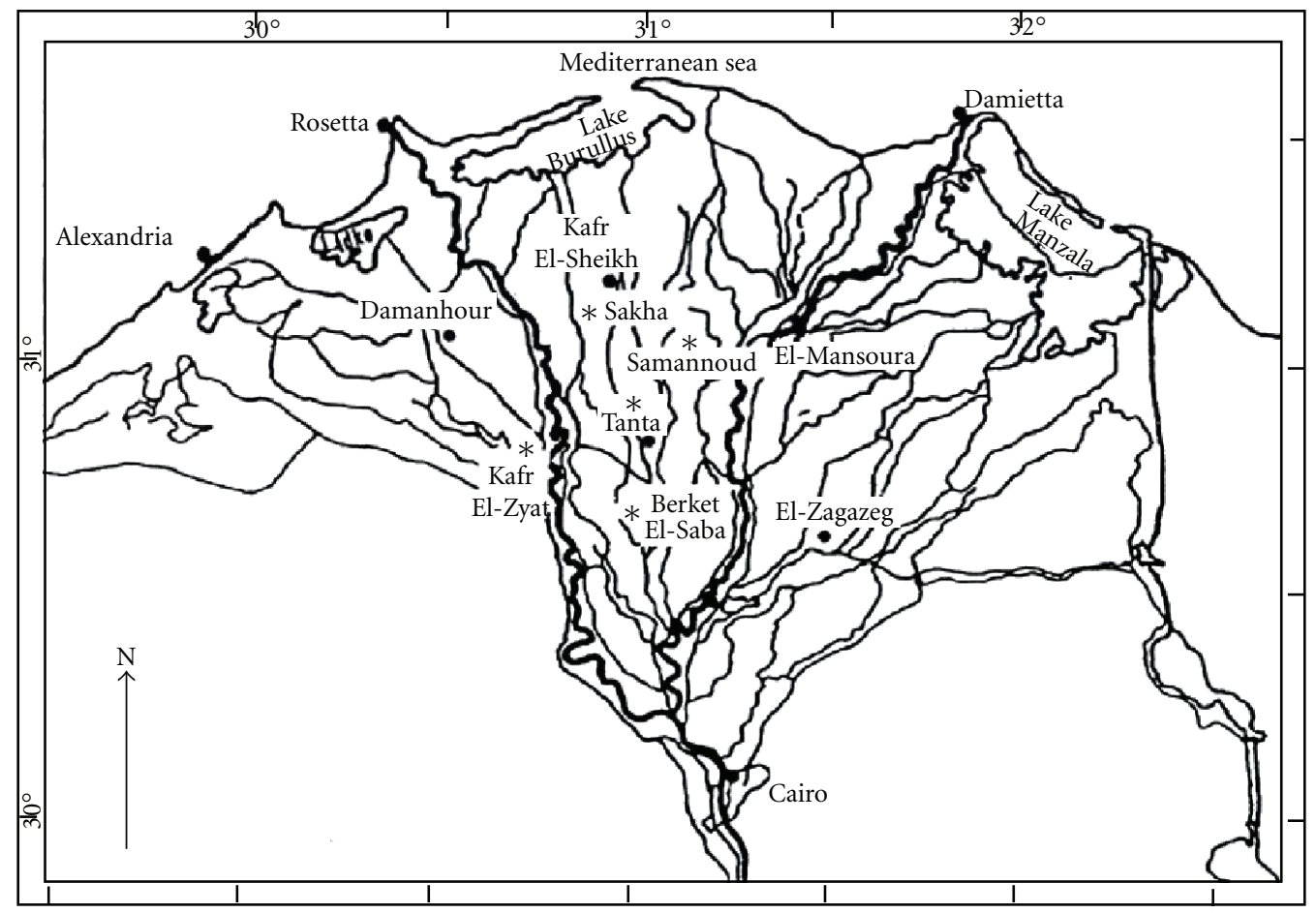

Figure 1: Map of the Nile Delta region of Egypt.* indicates the study area.

most macrophytes-dominated lakes with $\mathrm{P}$ concentration above $30 \mathrm{mg} \mathrm{m}^{-3}$ were dominated by C. demersum. C. demersum is a useful indicator of water pollution; it can trap macro- and microelements and accelerate the removal and biotransformation of herbicides from contaminated water [36]. Yaowakhan et al. [37] observed that, at high $\mathrm{Pb}$ concentration, $C$. demersum showed substantial accumulation, that is, $1621 \mathrm{mg} / \mathrm{kg}$ at $1 \mathrm{mg} / \mathrm{L} \mathrm{Pb}$ after 6 days and $6982 \mathrm{mg} / \mathrm{kg}$ at $10 \mathrm{mg} / \mathrm{L} \mathrm{Pb}$ after 9 days. The relative growth of plants generally decreased with increase in $\mathrm{Pb}$ concentration. Keskinkan et al. [38] reported that M. spicatum has a better adsorption capacity than $C$. demersum for $\mathrm{Zn}, \mathrm{Cu}$, and $\mathrm{Pb}$.

Ministry of Agriculture, Fisheries and Food in England (Anonymous [39]) reported that minimum protein in the animal diet ranges between 6 to $12 \%$ depending on the animal species. NRC [40] indicated that sheep are known to require $8.9 \%$ protein for maintenance. The average annual protein contents in the living part of E. stagnina and the dead parts of all species are far too low than the proper level, while those of $C$. demersum exceed the maintenance requirement. Comparing with the other fodder plants, the protein content in the living and dead parts of all species were lower than those of T. alexandrinum (16.2\%: [41]). The protein contents of the living and dead parts of all species agree with the scale of the protein content of some rough fodder materials (2.7\%-13.4\%: [42]) except E. stagnina. The same is true regarding ash content (1.3\%-23.1\%) except for C. demersum where their values exceed the upper limit of the range. The importance of lipids (i.e., ether extract) to plants, in terms of structure and use in metabolism, is well known. However, Chapin et al. [43] indicated that lipids are clearly unimportant as an energy source in some plants. Lipids of the living and dead parts of all species lay within the scale of some rough fodder materials $(0.5 \%-3.1 \%$ : [42]), but lower than those of T. alexandrinum (2.9\%: [41]). Total carbohydrates in the living and dead parts of all species lay with the range of some rough fodder material $(27.8-51.9 \%$ : [42]), but lower than those of T. alexandrinum (43.4\%: [41]). In addition, the crude fibers of all species were higher than that of T. alexandrinum (21.5\%: [41]) except those of $E$. crassipes which are relatively low.

DCP attained its maximum values $(11.3 \%)$ in the living parts of $C$. demersum. The value required for the diet of sheep is about $6.1 \%$ (NRC [34]). In general, straw and chaff of grasses have very low and often zero DCP [21]. DCP in Egyptian clover hay is about $9.0 \%$ [42]. It seems that the nutritive values of the living parts of the studied species are within the range of nutritive value of sheep [34], goat [44], dairy cattle [45], and beef cattle [24].

E. stagnina had the highest TDN in the living and dead parts, while $C$. demersum had the lowest. In comparison, Heneidy and Bidak [46] recorded a TDN average of $68.8 \%$ in P. australis, and El-Beheiry and El-Kady [47] reported a TDN of $50 \%$ in some Tamarix species. Abdel-Razik et al. [48] reported an annual range of $66.0 \%-75.0 \%$ in the Mediterranean coastal region of Egypt. Chauhan et al. [41] reported a value of $66.7 \%$ for Egyptian clover, while Shoukry [42] reported a range of $34.0 \%-48.0 \%$ for some rough fodder materials. The living parts of E. stagnina had the 


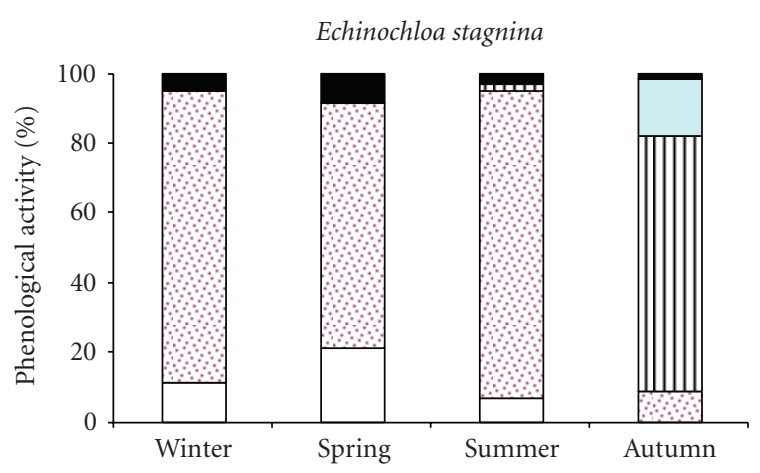

(a)

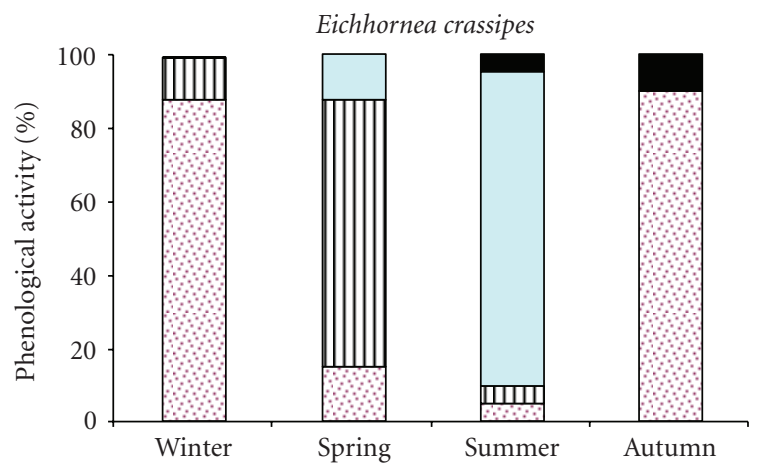

(b)

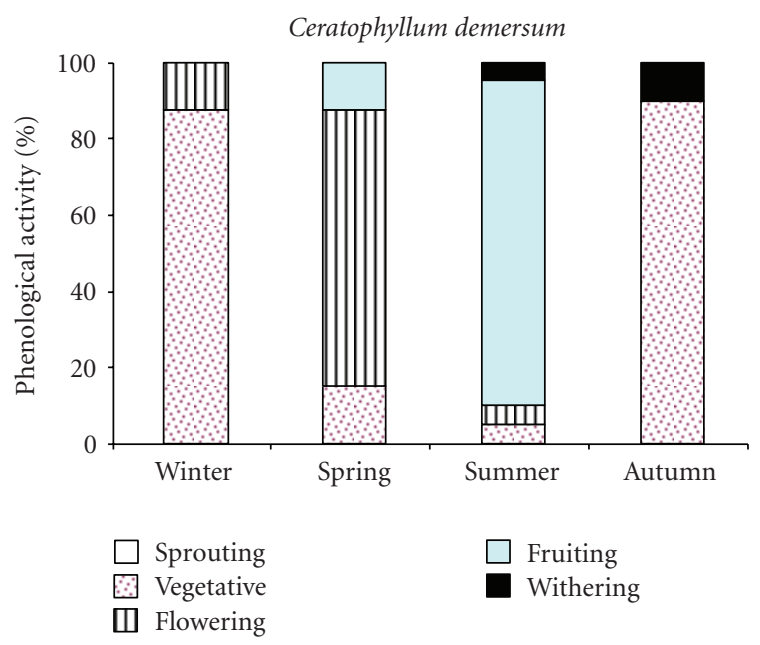

(c)

Figure 2: Phenological activity (\%) of the 3 studied species in the four seasons along the canals and drains in Nile Delta.

highest value of DE (2.8 Mcal kg-1), while C. demersum had the lowest. In comparison, cheeps are known to require 2.7 Mcal kg-1 for diet [34]. Heneidy and Bidak [46] reported $3.04 \mathrm{Mcal} \mathrm{kg}^{-1}$ for P. australis, while El-Kady [49] reported $2.4 \mathrm{Mcal} \mathrm{kg} \mathrm{kg}^{-1}$ and $2.2 \mathrm{Mcal} \mathrm{kg}^{-1}$ for the living and dead parts, respectively. Moreover, Chauhan et al. [41] reported

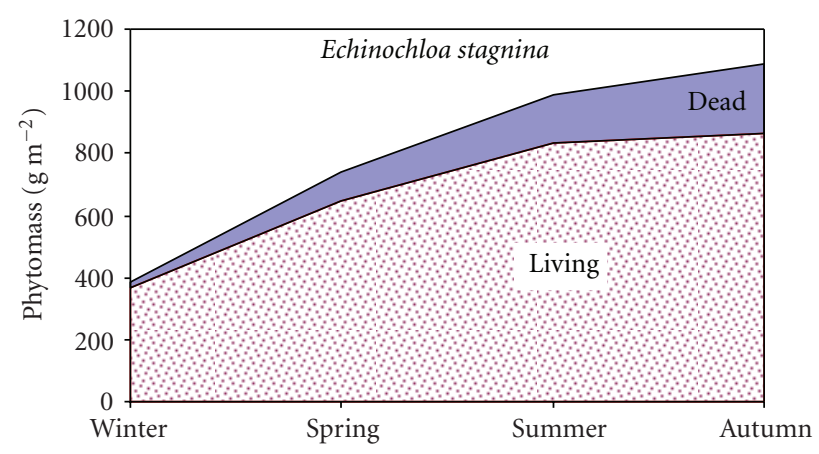

(a)

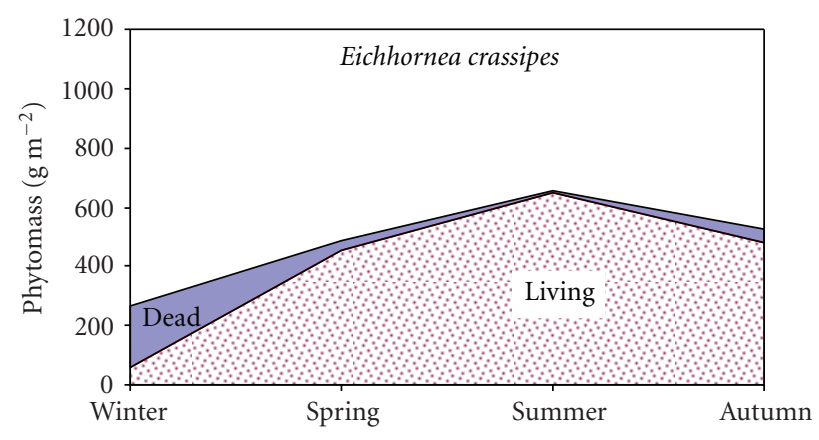

(b)

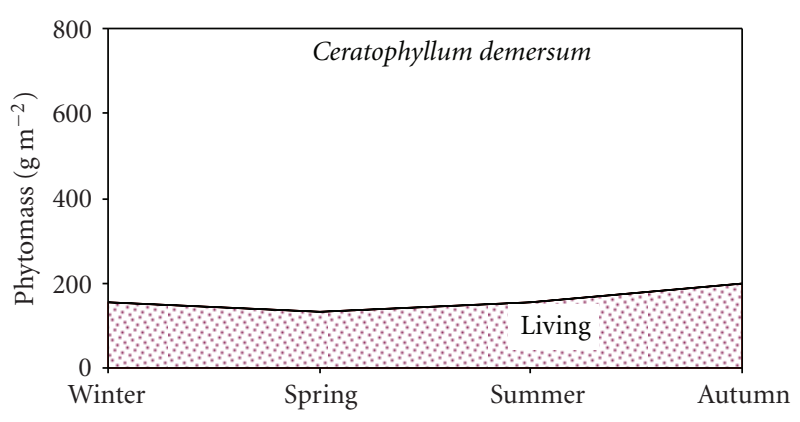

(c)

Figure 3: Phytomass of living (L) and dead (D) parts of the studied species in relation to the different seasons. T: total phytomass.

2.9 Mcal kg-1 for T. alexandrinum. The maximum ME was $2.3 \mathrm{Mcal} \mathrm{kg}^{-1}$ in the living parts of E. stagnina, while the minimum (1.5 Mcal kg$\left.{ }^{-1}\right)$ was in those of C. demersum. In comparable studies, $P$. australis had a value of $2.62 \mathrm{Mcal} \mathrm{kg}^{-1}$ [46] and T. alexandrinum had a value of $2.46 \mathrm{Mcal} \mathrm{kg}^{-1}$ [41]. The cheep and breeding cattle require 2.23 and $2.1 \mathrm{Mcal}$ $\mathrm{kg}^{-1}$, respectively, $\left.[24,34]\right)$. Using the scale suggested by Boudet and Riviere [50], the living parts of E. crassipes and C. demersum were considered as excellent forages, while the dead parts of all species and the living parts of E. stagnina were evaluated as poor forage. 


\section{References}

[1] M. A. Gabra, N. M. El-Kholy, S. Y. Sherif, and I. M. Soliman, "Chemical composition and feeding value of fooder beet (Beta vulgaris L.)," in Proceedings of the 1st Conference of Agricultural Development Research. Organized by Faculty of Agriculture, vol. 1, pp. 92-100, Ain Shams University, Cairo, Egypt, 1987.

[2] K. H. Shaltout and M. T. Khalil, "Lake Burullus: Burullus Protected Area," Publication of National Biodiversity Unit. no. 13, EEAA, Cairo, Egypt, 2005.

[3] S. M. Haslam, "River plants," in The Macrophytic Vegetation of Watercourses, pp. 1-390, Cambridge University Press, Cambridge, UK, 1976.

[4] M. Soerjani, "Environmental considerations in the novel approach of aquatic vegetation management," in Weeds and the Environment in the Tropics, K. Noda and B. L. Mercado, Eds., pp. 33-49, 1986.

[5] H. S. Vedanayagam, G. Lakshminarayan, and G. Thyagarayan, "A preliminary report on the use of water hyacinth for making paints," in Proceedings of the International Conference on Water Hyacinth, Hydearabad, India, 1983.

[6] S. Z. Haider, K. M. Malik, M. N. Rahman, and M. A. Ali, "Pollution control by water hyacinth of waste effluents of pulp and paper mills and of tanneries," in Proceedings of the International Conference on Water Hyacinth, pp. 1-54, Hydearabad, India, 1983.

[7] C. K. John, "Use of water hyacinth in the treatment of effluent from rubber and oil palm industries," in Proceedings of the International Conference on Water Hyacinth, pp. 1-60, Hyderabad, India, 1983.

[8] B. Gopal, "Perspectives on wetland science, application and policy," Hydrobiologia, vol. 490, pp. 1-10, 2003.

[9] J. K. Cronk and M. S. Fennessy, Wetlands Plants. Biology and Ecology, Lewis, Boca Raton, Fla, USA, 2001.

[10] P. A. Mays and G. S. Edwards, "Comparison of heavy metal accumulation in a natural wetland and constructed wetlands receiving acid mine drainage," Ecological Engineering, vol. 16, no. 4, pp. 487-500, 2001.

[11] E. Stoltz and M. Greger, "Accumulation properties of As, Cd, $\mathrm{Cu}, \mathrm{Pb}$ and $\mathrm{Zn}$ by four wetland plant species growing on submerged mine tailings," Environmental and Experimental Botany, vol. 47, no. 3, pp. 271-280, 2002.

[12] D. Baldantoni, A. Alfani, P. Di Tommasi, G. Bartoli, and A. V. De Santo, "Assessment of macro and microelement accumulation capability of two aquatic plants," Environmental Pollution, vol. 130, no. 2, pp. 149-156, 2004.

[13] A. Shata and I. El-Fayomi, "Remarks on the regional geological structure of the Nile Delta. Hydrogeology of Deltas," in Proceedings of the Bucharest Symposium, vol. 1, pp. 189-197, Jash/Aihs UNESCO, Paris, France, 1970.

[14] M. M. El-Gabaly, I. M. Gewaifet, and B. G. Rozanov, "Soils and soil regions of U.A.R.," Institute of Land Reclamation Research Bulletin, vol. 21, 1969.

[15] H. E. Hurst, The Nile, Constable, London, UK, 1952.

[16] A. F. Khattab and Z. El-Gharably, "The problem of aquatic weeds in Egypt and methods of management," in Design and Maintenance of Open Channels, pp. 114-130, Research Institute of Weed Control and Channel Maintenance, Water Research Center and Ministry of Public Works and Water Resources, 3rd edition, 1984.

[17] M. A. El-Sheikh, A study of the vegetation environmental relatioships of the canal banks of the middle Delta region, M.S. thesis, Faculty of Science, Tanta University, Tanta, Egypt, 1989.
[18] UNESCO, "Map of the world distribution of arid regions," MAB Technical Notes, 7, 1977.

[19] S. E. Allen, H. M. Grimshaw, J. A. Parkinson, C. Quamby, and J. D. Roberts, "Methods in plant ecology," P. D. Moore and S. B. Chapman, Eds., pp. 411-466, Blackwell Scientific, Oxford, UK, 2nd edition, 1986.

[20] K. Ölberg, "Factors affecting the nutritive value of range forage," Journal of Range Management, vol. 9, pp. 220-225, 1956.

[21] C. Demarquilly and P. Weiss, "Tableau de la valeur alimentaire des fourrages. Et. 42: Versailles INRA-SEI,” 1970.

[22] H. N. Le Houérou, "Chemical composition and nutritive value of browse in Tropical West Africa," in Browse in Africa, H. N. Le Houérou, Ed., pp. 261-289, ILCA, Addis Ababa, Ethiopia, 1980.

[23] M. A. Naga and K. El-Shazly, "The prediction of the nutritive value of animal feeds from chemical analysis," Journal of Agricultural Science, vol. 77, pp. 1-25, 1971.

[24] NRC, Nutrient Requirements of Domestic Animals: Nutrient Requirement of Cheep, National Research Council no. 5, National Academy of Sciences, Washington, DC, USA, 6th edition, 1984.

[25] W. N. Garrett, "Energy utilization of growing cattle as determined in seventy-two comparative slaughter experiments," in Energy Metabolism, L. E. Mount, Ed., vol. 26, EAAP, London, UK, 1980.

[26] SAS, SAS/STAT User's Guide, SAS Instruction Incorporation, Cary, NC, USA, 1985.

[27] R. T. Pine, L. W. J. Anderson, and S. S. O. Hung, "Notes on non-destructive estimation of aquatic macrophytes biomass," Journal of Aquatic Plant Management, vol. 27, pp. 47-49, 1989.

[28] S. El-Darier and L. Sadek, "Growth analysis and bioaccumulation of nutrient elements in the ecosystem of Eichhornia crassipes (Mart.) Solms-Laub," Desert Institute Bulletin, vol. 46, no. 1, pp. 71-89, 1996.

[29] S. S. Sastroutomo, "The role of aquatic vegetation in the environment," in Proceedings of the ANBS Workshop on Ecology and Management of Aquatic Vegetation in the Tropics, Jakarta, Indonesia, 1985.

[30] M. M. El-Fiky, Studies on the ecology of water plants with special reference to Eichhornia crassipes, M.S. thesis, Cairo University, Cairo, Egypt, 1974.

[31] K. R. Reddy, K. L. Campbell, D. A. Graetz, and K. M. Portier, "Use of biological filters for treating agricultural drainage effluents," Journal of Environmental Quality, vol. 11, no. 4, pp. 591-595, 1982.

[32] P. Miretzky, A. Saralegui, and A. F. Cirelli, "Aquatic macrophytes potential for the simultaneous removal of heavy metals (Buenos Aires, Argentina)," Chemosphere, vol. 57, no. 8, pp. 997-1005, 2004.

[33] S. Chanda, S. K. Bhaduri, and D. Sardar, "Chemical characterization of pressed fibrous residues of four aquatic weeds," Aquatic Botany, vol. 42, no. 1, pp. 81-85, 1991.

[34] NRC, Nutrient Requirements of Domestic Animals: Nutrient Requirement of Cheep, National Research Council no. 5, National Academy of Sciences, Washington, DC, USA, 5th edition, 1975.

[35] M. Mjelde and B. A. Faafeng, "Ceratophyllum demersum hampers phytoplankton development in some small Norwegian lakes over a wide range of phosphorus concentrations and geographical latitude," Freshwater Biology, vol. 37, no. 2, pp. 355-365, 1997.

[36] M. A. Zahran and A. J. Willis, Plant Life in the River Nile in Egypt, Mars Publishing House, Riyadh, Saudi Arabia, 2003. 
[37] P. Yaowakhan, M. Kruatrachue, P. Pokethitiyook, and V. Soonthornsarathool, "Removal of lead using some aquatic macrophytes," Bulletin of Environmental Contamination and Toxicology, vol. 75, no. 4, pp. 723-730, 2005.

[38] O. Keskinkan, M. Z. L. Goksu, A. Yuceer, and M. Basibuyuk, "Comparison of the adsorption capabilities of Myriophylum spicatum and Ceratophyllum demersum for zinc, copper and lead," Engineering in Life Sciences, vol. 7, no. 2, pp. 192-196, 2007.

[39] Anonymous, Energy Allowances and Feeding System for Ruminants, Ministry of Agriculture, Fisheries and Food. London, Her Majesty's Stationary Office, Technical Bulletin, 1975.

[40] NRC, Nutrient Requirements of Domestic Animals: Nutrient Requirement of Cheep, National Research Council no. 5, National Academy of Sciences, Washington, DC, USA, 6th edition, 1985.

[41] T. R. Chauhan, R. S. Gill, and J. S. Ichhponani, "Nutritive value of berseem and clusterbean forages," Indian Journal of Animal Sciences, vol. 50, no. 12, pp. 1052-1055, 1980.

[42] M. M. Shoukry, "An actual vision about the availability of the utilization of water hyacinth in feeding ruminants," in Proceedings of the National Symposium on Water Hyacinth, pp. 75-92, Assiut University, 1992.

[43] F. S. Chapin III, J. D. McKendrick, and D. A. Johnson, "Seasonal changes in carbon fractions in Alaskan tundra plants of differing growth form: implications for herbivory," Journal of Ecology, vol. 74, no. 3, pp. 707-731, 1986.

[44] NRC, Nutrient Requirements of Domestic Animals: Nutrient Requirement of Cheep, National Research Council no. 15, National Academy of Sciences, Washington, DC, USA, 1981.

[45] NRC, Nutrient Requirements of Domestic Animals: Nutrient Requirement of Cheep, National Research Council no. 3, National Academy of Sciences, Washington, DC, USA, 5th edition, 1978

[46] S. Z. Heneidy and L. M. Bidak, "Halophytes as forage source in the western Mediterranean coastal region of Egypt," Desert Institute Bulletin, vol. 46, no. 2, pp. 261-283, 1996.

[47] M. A. H. El-Beheiry and H. F. El-Kady, "Nutritive value of two Tamarix species in Egypt," Journal of Arid Environments, vol. 38, no. 4, pp. 529-539, 1998.

[48] M. Abdel-Razik, M. Ayyad, and S. Heneidy, "Preference of grazing mammals for forage species and their nutritive value in a Mediterranean desert ecosystem (Egypt)," Journal of Arid Environments, vol. 15, no. 3, pp. 297-305, 1988.

[49] H. El-Kady, "Seasonal variation in phytomass and nutrient status of Phragmites australis along the water courses in the Middle Delta region," Taekholmia, vol. 20, no. 2, pp. 123-138, 2002.

[50] G. Boudet and R. Rivière, "Emploi pratique des analyses fourragères pour l'appréciation des pâturages tropicaux," Revue d'Elevage et de Medecine Veterinaire des Pays Tropicaux, vol. 21, no. 2, pp. 227-266, 1968. 

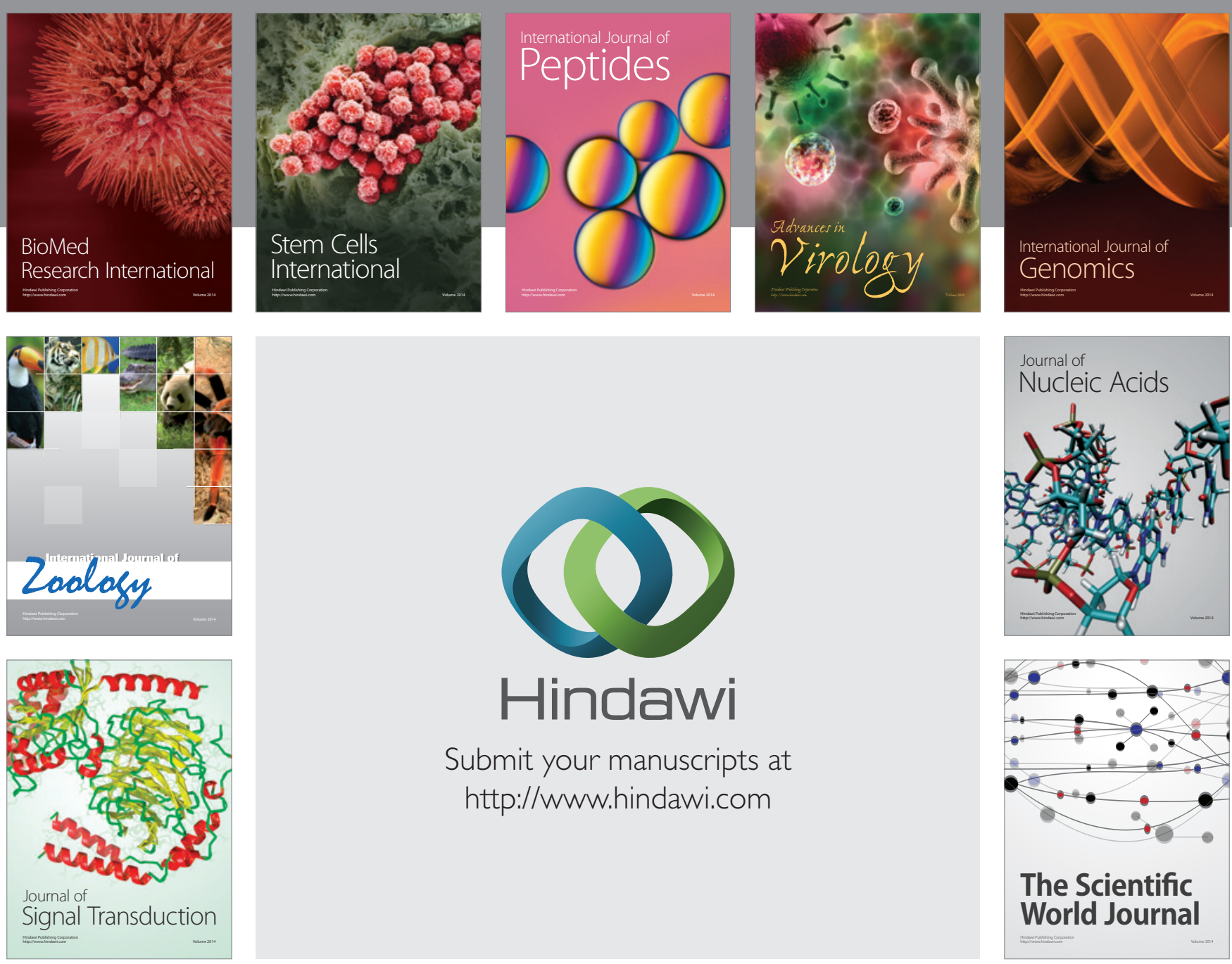

Submit your manuscripts at

http://www.hindawi.com
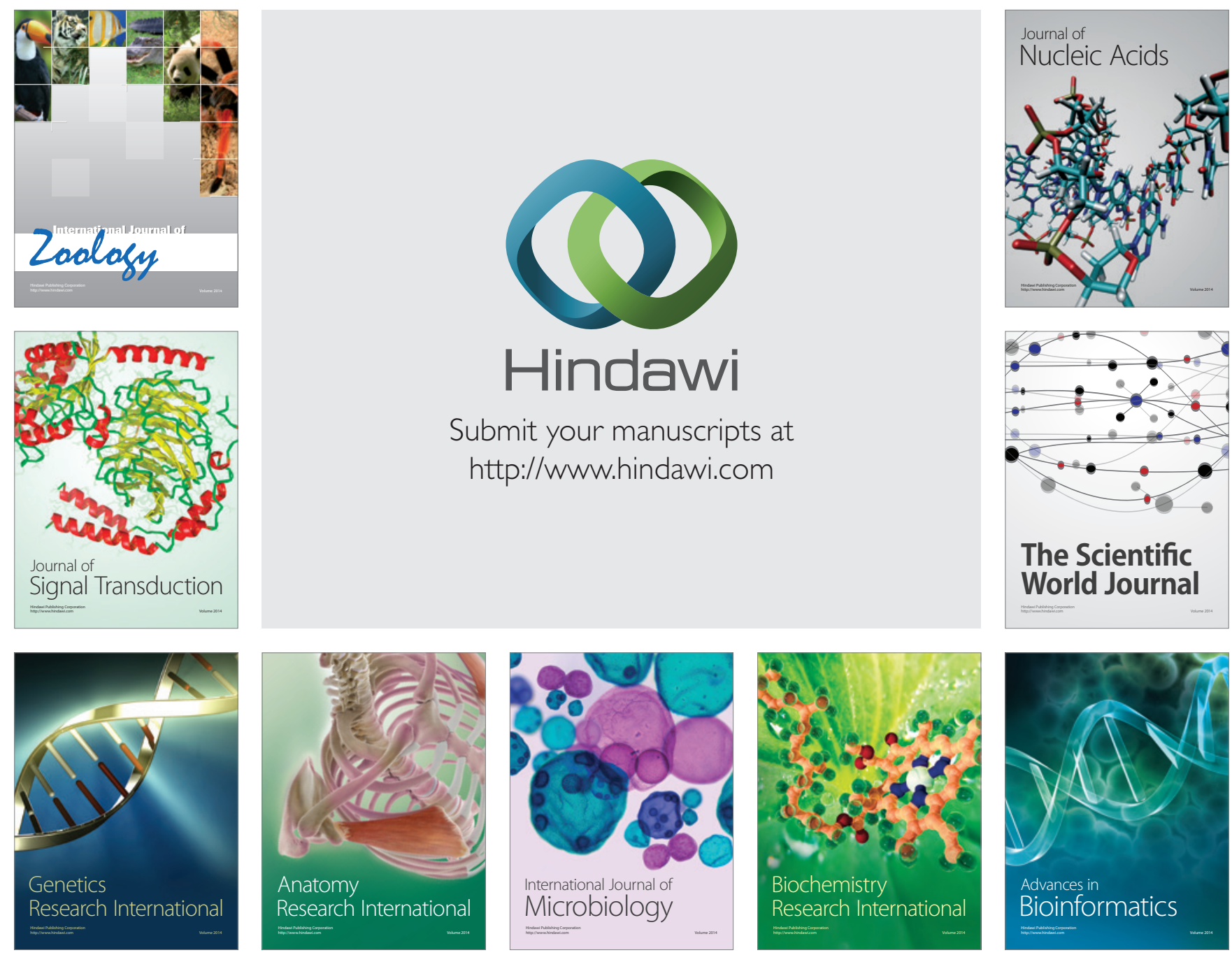

The Scientific World Journal
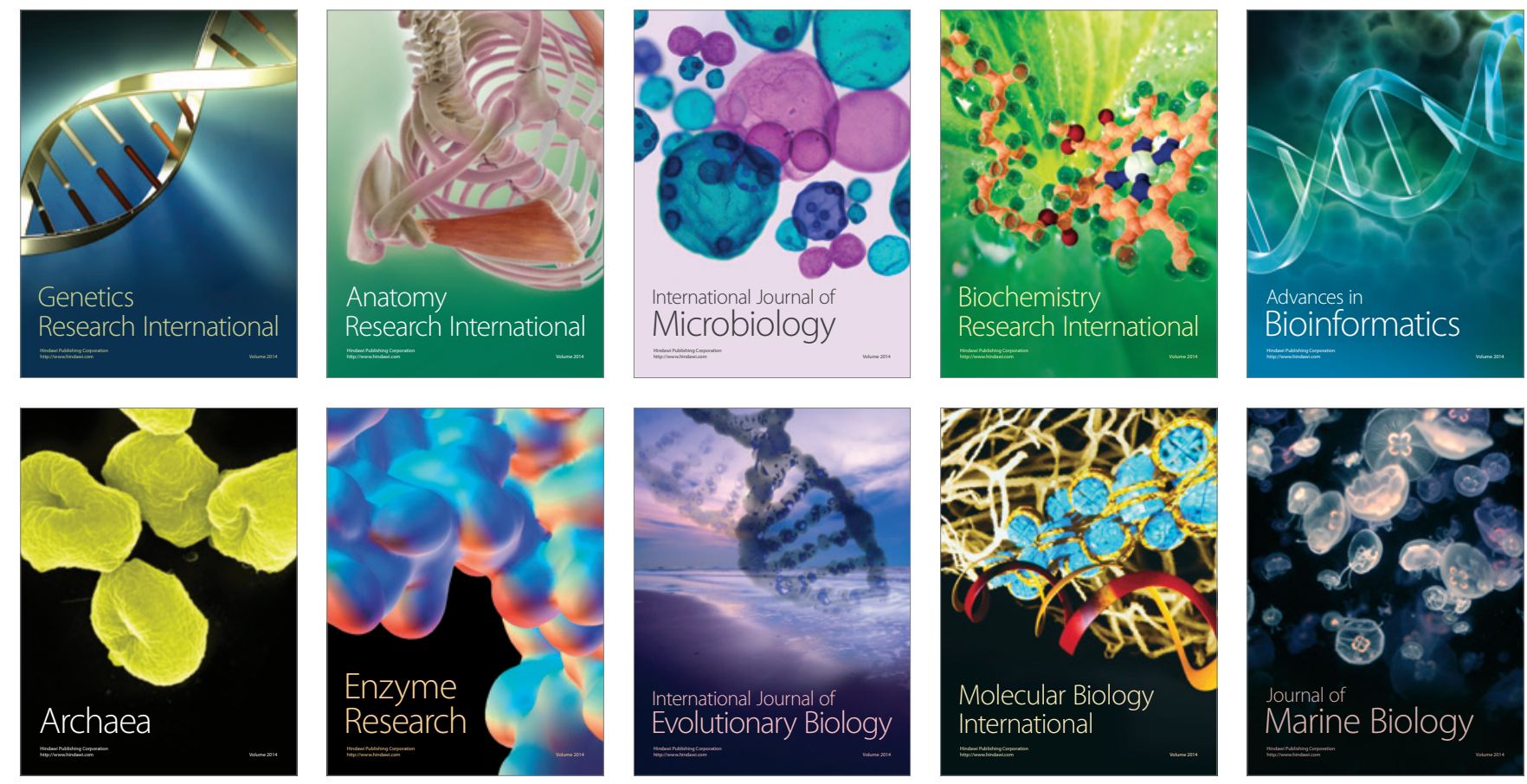